\title{
INTERNET DAN PERILAKU SEKSUAL REMAJA PESISIR MADURA: STUDI CROSS SECTIONAL DI DESA BRANTA
}

\author{
Shefa Dwijayanti Ramadani \\ Fakultas Keguruan dan Ilmu Pendidikan, Universitas Islam Madura \\ shefadwijayanti@gmail.com \\ Ina Daril Hanna \\ Fakultas Keguruan dan Ilmu Pendidikan, Universitas Islam Madura
}

\begin{abstract}
Abstrak
Salah satu masalah yang sering dihadapi remaja pada kota-kota maju sebagai akibat modernisasi dan westernisasi di era digital adalah penyimpangan perilaku seksual. Meskipun demikian, daerah pedesaan berpeluang untuk mengalami hal yang sama karena perkembangan teknologi informasi membuat segala hal menjadi tanpa batas (borderless). Penelitian bertujuan untuk mengungkap faktorfaktor yang berkaitan dengan penggunaan internet terhadap penyimpangan perilaku seksual remaja di wilayah pesisir Madura. Penelitian mengggunakan metode potong lintang (cross sectional). Sebanyak 80 responden berusia 12-20 tahun diplilih secara acak dari sejumlah sekolah (SD, SMP, dan SMA/SMK) di wilayah Desa Branta, Pamekasan, Madura. Data yang diperoleh melalui angket dan wawancara selanjutnya dianalisis deskriptif dan inferensial melalui uji Chi-Square. Hasil penelitian menunjukkan bahwa $91.71 \%$ responden telah terpapar konten pornografi saat mengakses internet dan sebanyak 50\% responden secara sengaja mengakses konten pornografi. Hasil penelitian juga menunjukkan bahwa faktor berupa jenis kelamin dan akses terhadap konten pornografi memiliki hubungan yang signifikan dengan penyimpangan perilaku seksual, sementara faktor keterpaparan konten pornografi dan intensitas konsumsi internet tidak menunjukkan hubungan yang signifikan. Dengan demikian, hasil penelitian mengindikasikan bahwa dampak negatif penggunaan internet dapat dialami oleh siapapun, termasuk para remaja di wilayah pedesaan. Peran serta berbagai pihak sangat diperlukan untuk mencegah serta memberikan bimbingan secara memadai sehingga internet dapat menjadi ruang yang lebih aman bagi remaja.
\end{abstract}

Kata Kunci: internet, perilaku seksual, remaja, madura

\begin{abstract}
One problem often faced by teenagers in developing cities as a result of modernization and westernization in digital era is the risk of sexual behavior. However, rural areas have the same opportunity to experience that problem because technology and information knowdays makes everything borderless. The aim of the study is to explore any factors related to internet misuse to teenagers's sexual behavior in rural area of Madura Island. The study used a cross sectional method. A total of 80 respondents aged 12-20 years were randomly selected from a number of schools (elementary, junior high school, and high school/ vocational school) in Branta village, Pamekasan, Madura. Data obtained through questionnaires and interviews were then analyzed descriptively and inferentially through the Chi-Square test. The results showed that $91.71 \%$ of respondents had been exposed to pornographic content while accessing the internet, as well as $50 \%$ of respondents' deliberately accessed pornographic content. The results also showed that sex and access to pornographic content had a significant relationship, while exposure to pormographic content and intensity of internet consumption did not show a significant relationship. Thus, the results of the study indicate that the negative impact of internet misuse can be experienced by anyone, including teenagers in rural areas. The participation of various parts is needed to provide adequate prevention and guidance so that the internet can be a safer space for teenagers.
\end{abstract}

Keywords: internet, sexual behavior, teenagers, madura. 


\section{PENDAHULUAN}

Perkembangan zaman telah melahirkan generasi digital yang sejak kelahirannya terpapar oleh gencarnya perkembangan teknologi dan informasi. Kelompok muda dari generasi ini telah mengenal teknologi dan akrab dengan gadget canggih yang secara tidak langsung berpengaruh terhadap nilainilai, pandangan, dan tujuan hidup mereka. Banyak harapan serta potensi yang dimiliki kelompok tersebut untuk menjadi generasi profesional yang canggih. Namun di lain pihak, tidak sedikit tantangan yang harus dihadapi.

Salah satu tantangan yang dihadapi oleh remaja di era teknologi dan informasi adalah paparan berbagai konten negatif, termasuk hal-hal yang berbau seksualitas yang dapat muncul ketika mereka mengakses internet. Data terbaru menunjukkan bahwa setidaknya 30 juta anak-anak dan remaja Indonesia adalah pengguna internet, dan media digital menjadi pilihan utama saluran komunikasi yang mereka gunakan (Kominfo, 2014). Hal yang cukup mencengangkan juga terungkap dari survey Badan Pusat Statistik (BPS) bahwa pengakses internet paling muda didapati berada pada rentang usia 5 sampai 12 tahun (Badan Pusat Statistik, 2012). Padahal pada masa tersebut para remaja bahkan anak-anak masih sulit melindungi diri dari dampak negatif penggunaan internet.

Remaja merupakan fase kehidupan yang penting dalam siklus perkembangan individu. Fase ini merupakan masa transisi yang dapat diarahkan pada perkembangan masa dewasa yang sehat, sehingga membawa kebahagiaan dan kesuksesan dalam menjalankan tugas-tugas perkembangan pada fase berikutnya. Demikian pula sebaliknya, remaja yang tidak mampu menjalankan tugas-tugas perkembangannya dengan baik akan mengakibatkan ketidakbahagiaan, menimbulkan penolakan dari masyarakat, dan kesulitan dalam menuntaskan tugastugas pada fase perkembangan selanjutnya (Putro, 2017).

Remaja dalam tahap perkembangan psikososialnya telah mengembangkan keterampilan berpikir, bertindak, dan pengaruh sosial yang lebih kompleks. Akan tetapi, kondisi semacam ini tidak selalu sama pada setiap individu, bergantung pada kondisi pribadi atau pengaruh lingkungan di sekitar individu. Masalah pornografi dalam berbagai bentuk, baik secara sengaja atau tidak sengaja dikonsumsi oleh remaja pada saat mengakses internet akan menggiring mereka pada degradasi mental serta mendorong munculnya penyimpangan perilaku seksual. Ditambah lagi sebagai dampak dari pola perkembangan yang pesat di dalam diri remaja, umumnya mereka memiliki rasa ingin tahu yang besar, menyukai petualangan dan tantangan, serta berani untuk mengambil resiko (Depkes, 2019). Keadaan ini sering mendatangkan konflik batin dalam dirinya. Apabila keputusan yang diambil untuk mengatasi konflik tersebut tidak tepat, maka mereka akan semakin terjebak pada penyimpangan perilaku seksual dan mungkin harus menanggung akibatnya seumur hidup.

Sampai dengan saat ini, informasi mengenai hubungan antara penggunaan internet dengan penyimpangan perilaku seksual remaja Indonesia masih sangat terbatas. Hasil penelitian yang telah dilakukan sebelumnya hanya mengungkap temuantemuan terkait penyimpangan seksual di negaranegara maju (Brown \& L'Engle, 2009; Strasburger et al. 2010; Lo \& Wei, 2005; Ucar et al. 2016) maupun kota-kota besar di Indonesia, seperti Jakarta, Bandung, Surabaya, Medan, Makasar, dan Yogyakarta (BKKBN, 2012; Hidayaningsih, 2014; Lestari \& Kusmiyati, 2015). Hal ini lebih mudah dipahami karena pada negara dan kota-kota maju lebih banyak terpapar efek modernisasi dan westernisasi. Namun demikian, kondisi serupa juga mungkin dijumpai pada daerah pedesaan mengingat perkembangan teknologi informasi membuat segala hal menjadi tanpa batas (borderless). Oleh karenanya, upaya untuk mengungkap hubungan antara penggunaan internet dengan penyimpangan perilaku seksual pada remaja di pesisir Madura sangat penting untuk segera dilakukan.

Informasi yang diperoleh dari hasil kajian ini akan sangat bermanfaat terutama untuk melengkapi informasi yang belum tersedia tentang kondisi penyimpangan seksual di wilayah pedesaan, terutama di wilayah pesisir Madura. Terlebih masyarakat Madura selama ini dikenal sebagai etnik yang religius dan fanatik terhadap agamanya, 
dimana kesopanan, kehormatan, dan Islam menjadi pegangan (Adib, 2009). Informasi yang diperoleh melalui kajian ini juga sangat berguna bagi berbagai pihak yang berkepentingan, terutama dalam upaya pengambilan keputusan dan kebijakan dalam memberikan layanan pendidikan seksual dan reproduksi secara lebih dini dan efektif, khususnya pada daerah pinggiran yang belum banyak mendapatkan perhatian.

\section{METODE}

Penelitian menggunakan metode potong lintang (cross sectional) yakni variabel independen dan variabel dependen diukur dalam kurun waktu bersamaan. Variabel dependen adalah perilaku seksual remaja, sedangkan variabel independen adalah sejumlah faktor determinan terkait penyalahgunaan internet yaitu jenis kelamin, keterpaparan konten pornografi, akses konten pornografi, dan intensitas penggunaan internet.

Penelitian dilaksanakan selama bulan AprilAgustus 2019 di Desa Branta, Kecamatan Tlanakan, Kabupaten Pamekasan, Madura. Populasi penelitian meliputi seluruh remaja di desa Branta, sementara sampel penelitian adalah sebanyak 80 responden pada rentang usia 12-20 tahun sebagai representasi usia remaja awal, remaja tengah, dan remaja akhir. Pengambilan sampel dilakukan secara acak melalui stratified random sampling. Cara pengambilan sampel ini dilakukan dengan membagi populasi menjadi strata-strata atau sub populasi (tingkat SD, SMP, dan SMA/SMK), kemudian setelah menjelaskan tujuan dari studi yang hendak dilakukan kepada para siswa, diperoleh sebanyak 80 siswa yang setuju untuk berpartisipasi dan menjadi sampel penelitian.

Data penelitian yang dikumpulan meliputi jenis kelamin, keterpaparan konten pornografi, akses konten pornografi, dan intensitas penggunaan internet. Data berupa keterpaparan terhadap konten pornografi diketahui dengan mengkategorikan responden pada kelompok yang pernah memperoleh konten pornografi baik secara sengaja/tidak sengaja saat menggunakan internet, atau yang tidak pernah memperoleh konten tersebut. Akses remaja terhadap konten pornografi diketahui dengan mengkategorikan responden yang secara sengaja menggunakan internet untuk mengakses konten pornografi dengan kelompok yang tidak melakukan aktivitas tersebut. Adapun intensitas penggunaan internet diketahui berdasarkan durasi penggunaan internet dalam sehari. Tingkat konsumsi internet dalam sehari dibagi ke dalam 3 ketegori yaitu tingkat konsumsi rendah (kurang dari 1 jam sampai 1 jam), sedang (2-3 jam), dan tinggi (lebih dari 4 jam). Sementara itu, data berupa penyimpangan perilaku seksual yang dimaksud adalah kegiatan yang dilakukan dengan lawan jenis, dikategorikan sebagai perilaku belum beresiko (touching, kissing) dan perilaku beresiko (petting, sexual intercourse). Meskipun demikian, perilaku beresiko umumnya didahului dengan aktivitas yang tidak beresiko.

Data yang diperoleh melalui pengisian kuesioner dan wawancara tatap muka (face to face interview) selanjutnya dianalisis menggunakan teknik statistik deskriptif dan inferensial. Teknik deskriptif digunakan untuk memperoleh gambaran mengenai distribusi frekuensi dan proporsi dari masing-masing variabel. Untuk mengetahui hubungan antara penggunaan internet dengan penyimpangan perilaku seksual digunakan statistik inferensial melalui uji Chi-Square dengan taraf signifikansi sebesar 0,05

\section{HASIL DAN PEMBAHASAN}

\section{Karakteristik Responden}

Identifikasi penggunaan internet dan perilaku seksual remaja dilaksanakan dengan melibatkan sebanyak 80 responden di wilayah Desa Branta, Kecamatan Tlanakan, Pamekasan, Madura. Responden terdiri atas 42 remaja laki-laki $(52,5 \%)$ dan 38 remaja perempuan $(47,5 \%)$. Rentang usia responden yakni antara 12 hingga 20 tahun sebagai representasi usia remaja awal, usia remaja pertengahan, dan usia remaja akhir sebagaimana ditunjukkan pada Tabel 1 berikut.

Tabel 1. Distribusi Responden Menurut Usia

\begin{tabular}{l|c|c}
\hline \multicolumn{1}{c|}{ Rentang usia } & Frekuensi & Persentase \\
\hline Remaja awal (12-14 th) & 17 & $21,25 \%$ \\
Remaja tengah (15-17 th) & 59 & $73,75 \%$ \\
Remaja akhir (18-20 th) & 4 & $5 \%$ \\
\hline
\end{tabular}

\section{Penggunaan Perangkat Digital}

Hasil penelitian mengungkap bahwa seluruh subjek penelitian (100\%) memiliki sedikitnya 1 buah gadget/smartphone; serta menggunakan gadget 
tersebut untuk mengakses internet dibandingkan dengan perangkat lainnya seperti laptop dan komputer. Intensitas penggunaan internet oleh remaja dalam sehari dapat dikategorikan dalam tiga tingkatan, yaitu sebanyak 37.5\% responden memiliki tingkat konsumsi rendah terhadap internet (kurang dari 1 jam sampai 1 jam); $36.25 \%$ pada ketegori sedang (2-3 jam); dan $26.25 \%$ pada kategori tinggi (lebih dari 4 jam).

\section{Penggunaan Internet dan Akses Konten Pornografi}

Gambaran distribusi responden dalam menggunakan internet dan akses terhadap konten pornografi dapat diamati pada Tabel 2. Pada Tabel tersebut diketahui bahwa diantara seluruh responden dalam penelitian ini, hampir seluruhnya yakni sebesar $91.25 \%$ telah terpapar konten pornografi pada saat mengakses internet. Konten pornografi tersebut muncul secara tidak sengaja melalui iklan atau secara tidak sengaja muncul dalam beranda sosial media yang kemudian menarik perhatian responden untuk mengamati konten tersebut. Sementara itu, terungkap pula bahwa sebanyak 35\% responden secara sengaja menggunakan internet untuk mengakses berbagai konten konten yang bersifat erotis dan tergolong pornografi, baik dalam bentuk gambar maupun video/film.

Akses terhadap konten pornografi juga secara signifikan lebih banyak dilakukan oleh remaja lakilaki dibandingkan remaja perempuan (Tabel 3; p $<0.05$ ). Ironisnya, sebagian besar responden merasa bahwa aktivitas menonton konten pornografi tersebut menyenangkan $(46,4 \%)$, sementara lainnya merasa penasaran $(25 \%)$ dan biasa saja $(28,6 \%)$.

Dalam kaitannya dengan penggunaan internet dan perilaku seksual remaja, hasil analisis juga menunjukkan bahwa tidak ada hubungan antara keterpaparan konten pornografi pada saat remaja menggunakan internet dengan penyimpangan perilaku seksual $(\mathrm{p}>0.05)$. Penjelasan atas hasil analisis tersebut berkaitan dengan kondisi responden dalam studi ini yang cenderung homogen, yakni sebanyak $91.25 \%$ responden telah terpapar konten pornografi pada saat mengakses internet. Sementara itu, mengakses konten pornografi yang dilakukan secara sengaja oleh remaja berhubungan secara signifikan dengan penyimpangan perilaku seksual $(p<0.05)$. Adapun intensitas penggunaan internet yang dilakukan oleh remaja, juga tidak berpengaruh secara signifikan dengan penyimpangan perilaku seksual remaja ( $p>0.05)$. Hasil uji interdependensi antara variabel penggunaan internet dengan variabel perilaku seksual dapat dilihat pada Tabel 3.

Tabel 2. Distribusi responden yang menggunakan internet untuk akses konten pornografi

\begin{tabular}{|c|c|c|}
\hline & & $\mathrm{n}(\%)$ \\
\hline Penggunaan teknologi digital $(\mathrm{n}=80)$ & $(\%)$ & 80 \\
\hline $\begin{array}{l}\text { Menggunakan gadget untuk akses } \\
\text { internet }(\mathrm{n}=80)\end{array}$ & 100 & $(100)$ \\
\hline Keterpaparan terhadap konten & $(\%)$ & 80 \\
\hline pornografi saat menggunakan internet & 65.0 & $(100)$ \\
\hline$(\mathrm{n}=80)$ & 35.0 & \\
\hline
\end{tabular}

Secara tidak sengaja mengakses konten pornografi

Secara sengaja mengakses konten pornografi

\begin{tabular}{lcc}
\hline Alasan yang mendorong responden & $(\%)$ & 28 \\
untuk mengakses konten pornografi & 35.7 & $(35.0)$ \\
$(\mathrm{n}=28)$ & 21.4 & \\
Penasaran/ingin tahu & 0.0 & \\
Mencari hiburan untuk menghilangkan & 42.8 & \\
stress & 0.0 &
\end{tabular}

Kebiasaan

Diajak teman

Lainnya

\begin{tabular}{lcc}
\hline Lokasi yang biasa digunakan untuk & & 28 \\
akses konten pornografi & $(\%)$ & $(35.0)$ \\
$(\mathrm{n}=28)$ & 42.8 & \\
Di rumah sendiri & 53.6 & \\
Di rumah teman & 0.0 & \\
Di rumah saudara & 3.6 & \\
Di sekolah & 0.0 & \\
Di tempat lainnya & & \\
\hline Persepsi saat mengakses konten & $(\%)$ & 28 \\
pornografi (n=28) & 25.0 & $(35.0)$ \\
Kaget dan penasaran & 28.6 & \\
Biasa saja & 46.4 & \\
Menyenangkan & & \\
\hline
\end{tabular}

Tabel 4. Hasil Ringkasan Uji interdependensi variabel penggunaan internet dengan perilaku seksual remaja

\begin{tabular}{clll}
\hline \multirow{2}{*}{$\begin{array}{c}\text { Penggunaan } \\
\text { internet }\end{array}$} & \multicolumn{3}{c}{ Perilaku Seksual } \\
\cline { 2 - 4 } & $\begin{array}{c}\text { Chi- } \\
\text { Squarehitung }\end{array}$ & $\begin{array}{c}\text { Chi- } \\
\text { Squaretabel }\end{array}$ & p \\
\hline Jenis kelamin & 19.056 & 3.841 & 0.000 \\
\hline
\end{tabular}




\begin{tabular}{|c|c|c|c|}
\hline \multirow{2}{*}{$\begin{array}{c}\text { Penggunaan } \\
\text { internet }\end{array}$} & \multicolumn{3}{|c|}{ Perilaku Seksual } \\
\hline & $\begin{array}{c}\text { Chi- } \\
\text { Squarehitung }\end{array}$ & $\begin{array}{c}\text { Chi- } \\
\text { Squaretabel }\end{array}$ & $\mathbf{p}$ \\
\hline $\begin{array}{l}\text { Keterpaparan } \\
\text { konten } \\
\text { pornografi }\end{array}$ & 3.908 & 5.991 & 1.420 \\
\hline $\begin{array}{l}\text { Akses Terhadap } \\
\text { Konten } \\
\text { pornografi }\end{array}$ & 54.953 & 5.991 & 0.000 \\
\hline $\begin{array}{l}\text { Intensitas } \\
\text { konsumsi } \\
\text { internet dalam } \\
\text { sehari }\end{array}$ & 3.963 & 9.488 & 0.411 \\
\hline
\end{tabular}

Gambaran penggunaan teknologi digital dalam bentuk internet oleh remaja di wilayah pinggiran menunjukkan bahwa generasi muda milenial saat ini menghabiskan hari-harinya dengan di kelilingi oleh berbagai perangkat digital termasuk smartphone. Mereka tidak mengenal dunia tanpa smartphone dan internet, serta tidak pula memandangnya sebagai alat, tetapi lebih sebagai bagian integral dari kehidupan mereka (Prensky, 2001). Hal ini terbukti dari hasil penelitian yang mengungkap bahwa seluruh responden setidaknya memiliki satu buah smartphone yang memiliki akses internet. Jika mengikuti teori kebutuhan Maslow, maka bagi generasi muda, internet sudah masuk dalam piramida dasar bersama sandang, pangan, dan papan (Ali \& Purwandi, 2017). Terlebih, semakin berkembangnya smartphone pada masa kini membuat kemudahan untuk mengakses internet semakin besar, sehingga akses internet dapat dilakukan kapanpun dan dimanapun.

Suatu hal yang tidak dapat dipungkiri bahwa berbagai aktivitas digital (termasuk mengunakan internet) yang dilakukan anak dan remaja mampu mendorong mereka untuk mengembangkan kreativitas, jati diri, penerimaan terhadap keberagaman, peningkatan literasi, maupun mengembangkan jaringan sosial (Strasburger et al., 2010). Akan tetapi, penggunaan internet juga berpeluang besar untuk memberikan pengaruh buruk bagi kehidupan anak dan remaja.

Hasil penelitian mengungkap bahwa hampir seluruh responden dalam penelitian ini yaitu sebesar 91,25\% telah terpapar konten pornografi pada saat mengakses internet. Konten pornografi tersebut muncul secara tidak sengaja melalui iklan, atau secara tidak sengaja muncul dalam beranda sosial media yang kemudian menarik perhatian remaja untuk mengamati konten tersebut. Meskipun demikian, terungkap pula bahwa terdapat 35\% responden secara sengaja menggunakan internet untuk mengakses berbagai konten yang bersifat erotis dan tergolong pornografi, baik dalam bentuk gambar maupun video/film.

Hasil analisis menunjukkan bahwa akses terhadap konten pornografi berhubungan secara signifikan dengan penyimpangan perilaku seksual pada remaja $(\mathrm{p}<0.05)$. Hal ini sejalan dengan laporan Strasburger et al. (2010) bahwa teknologi digital (termasuk internet) berpengaruh terhadap beberapa perilaku menyimpang remaja seperti agresi, perilaku seksual beresiko, penyalahgunaan obat-obatan terlarang, kelainan pola makan, dan kesulitan belajar. Brown \& L'Engle (2009) juga menambahkan bahwa paparan media yang mengandung konten seksual juga terbukti mampu meningkatkan godaan seksual pada siswa SMP, sehingga mereka lebih banyak melanggar norma asusila, lebih banyak melakukan oral sex, dan melakukan sexual intercourse pada saat SMA.

Teknologi digital tidak hanya mempengaruhi generasi muda dengan mengalihkan waktu untuk belajar atau tidur, tetapi justru dengan mempengaruhi keyakinan dan perilaku (Strasburger et al., 2010). Menurut teori belajar sosial, anak-anak dan remaja belajar melalui mengamati dan meniru apa yang mereka lihat di layar, terutama yang terlihat nyata atau dihargai (Bandura, 2009). Remaja yang terpapar media pornografi secara terus menerus akan semakin besar hasrat seksualnya (Santrock \& Curl, 2003; Bleakley et al., 2008). Pesan seksual yang diterima dari media pornografi secara konsisten berupa touching, kissing, petting, bahkan sexual intercourse juga sangat jarang diikuti dengan dampak dari perilaku tersebut, misalnya kehamilan yang tidak diinginkan, resiko terinfeksi penyakit menular seksual, aborsi, dan sebagainya. Hal yang mereka amati hanyalah sebatas kesenangan dan kepuasan seksual, sehingga mendorong mereka untuk meniru apa yang disaksikan tanpa berpikir panjang terhadap resiko yang mungkin dihadapi.

Variabel independen yang secara signifikan berhubungan dengan perilaku penyimpangan seksual pada remaja selain faktor akses terhadap konten 
pornografi adalah jenis kelamin. Remaja laki-laki diketahui paling dominan melakukan penyimpangan perilaku seksual dibandingkan dengan remaja perempuan $\quad(\mathrm{p}=0.007 ; \quad \mathrm{OR}=0.248 ; 95 \% \mathrm{Cl}=0.90$ 0.688).

Dalam kaitannya dengan penyimpangan perilaku seksual para remaja di wilayah Desa Branta, wilayah pesisir pulau Madura, gambaran yang diperoleh barangkali tidak separah temuan di negara-negara maju (Strasburger et al, 2010; Brown \& L'Engle, 2009) maupun kota-kota besar Indonesia seperti Jakarta, Bandung, Surabaya, Medan, Makasar, dan Yogyakarta (BKKBN, 2012; Hidayaningsih, 2014; Lestari \& Kusmiyati, 2015; Lestary \& Sugiharti, 2007). Meskipun demikian, kondisi yang terekam di salah satu wilayah pedesaan pinggiran pulau Madura menyadarkan bahwa resiko penyimpangan perilaku seksual dan pergaulan bebas adalah ancaman yang harus segera di atasi bersama melalui pendidikan reproduksi secara lebih efektif dengan memperhatikan penggunaan teknologi digital yang membuat segala hal kini menjadi tanpa batas (borderless).

\section{KESIMPULAN}

Dari hasil penelitian ini diketahui bahwa hampir seluruh responden $(91.71 \%)$ telah terpapar konten pornografi saat mengakses internet dan sebanyak $50 \%$ diantaranya secara sengaja mengakses konten pornografi. Hasil penelitian juga menunjukkan bahwa faktor-faktor yang secara signifikan berhubungan dengan penggunaan internet dan perilaku seksual adalah jenis kelamin dan akses terhadap konten pornografi, sementara faktor keterpaparan konten pornografi dan intensitas konsumsi internet tidak menunjukkan hubungan yang signifikan.

\section{Saran}

Penelitian ini memiliki keterbatasan dalam jumlah responden sebab keinginan untuk berbagi masalah seksualitas dengan orang lain masih menjadi hal yang tabu bagi masyarakat Madura. Meskipun demikian, kajian ini dapat memberikan informasi tentang penggunaan internet dan perilaku seksual pada kalangan muda di pesisir Desa Branta, Madura. Oleh karenanya, penelitian sejenis dapat dikaji lebih jauh dengan melibatkan lebih banyak populasi; melibatkan kelompok masyarakat yang lebih beragam; maupun pada wilayah dengan karakteristik yang berbeda. Upaya ini perlu dilakukan sebagai rekomendasi bagi pihak terkait untuk menyusun kebijakan maupun strategi pencegahan atas perilaku negatif yang mungkin ditimbulkan dari penyalahgunaan internet.

\section{DAFTAR PUSTAKA}

Adib, M. 2009. Etnografi Madura. Surabaya: Pustaka Intelektual.

Ali, H. \& Purwandi, L. 2017. The Urban MiddleClass-Millenials Indonesia: Financial and Online Behavior. Jakarta: PT. Alvara Strategi Indonesia. Diunduh dari http://alvarastrategic.com/wpcontent/uploads/whitepaper/The-Urban-MiddleClass-Millenials.pdf, pada tanggal 9 Agustus 2018.

Bleakley, A., Hennesy, M., Fishbein, M., Jordan, A. 2008. It works both ways: the relationship between sexual content in the media and adolescent sexual behavior. Media Psychol, 11(4): 443-461.

Bandura A. 2009. Social cognitive theory of mass communication. Media effects. Routledge, 110140.

Badan Koordinasi Keluarga Berencana Nasional (BKKBN). 2012. Makin banyak remaja melakuka seks pranikah. Diunduh dari http://ceria.bkkbn.go.id/ceria/referensi/artikel/det ail/56, pada tanggal 1 Agustus 2018 .

Badan Pusat Statistik. 2012. Statistik telekomunikasi Indonesia 2012. Jakarta: Badan Pusat Statistik.

Brown, J.D. \& L'Engle, K.L. 2009. X-rated: sexual attitudes and behaviors associated with US early adolescents' exposure to sexually explicit media. Communication research, 36(1): 129-151.

Depkes, R.I. 2009. Kesehatan reproduksi. Jakarta: Depkes RI.

Hidayaningsih, P. S. 2014. Perilaku Beresiko dan permasalahan reproduksi pada remaja. Jurnal Kesehatan Reproduksi, 5(2): 89-101.

Kominfo. 2014. Riset kominfo dan UNICEF mengenai perilaku anak dan remaja dalam menggunakan internet. Diunduh dari https://kominfo.go.id/index.php/content/detail/38 34/ , pada tanggal 8 Agustus 2019. 
Lestari, A. Y., \& Kusmiyati, Y. 2015. Hubungan Intensitas Mengakses Situs Porno Dengan Perilaku Seksual Pranikah Remaja. Jurnal Kesehatan Ibu Dan Anak, 7(1): 5-9.

Lestary, H. \& Sugiharti. (2007). Perilaku berisiko remaja di indonesia menurut survey kesehatan reproduksi remaja indonesia (SKRRI) tahun 2007. Jurnal Kesehatan Reproduksi, 1(3): 136144.

Lo, V. H. \& Wei, R. 2005. Exposure to internet pornography and Taiwanese adolescents' sexual attitudes and behaviour. Journal of Broadcasting \& Electronic Media, 49(2): 221-237.

Prensky, M. 2001. Digital natives, digital immigrants part 1. On the horizon, 9(5): 1-6.

Putro, K. Z. 2017. Memahami ciri dan tugas perkembangan masa remaja. Aplikasia: Jurnal Aplikasi Ilmu-ilmu Agama, 17(1): 25-32.

Santrock, J. W., \& Curl, R. M. (2003). Adolescence (9th ed.). New York: McGraw-Hill.

Strasburger, V. C., Jordan, A. B., \& Donnerstein, E. (2010). Health effects of media on children and adolescents. Pediatrics, peds-2009.

Ucar, T., Golbasi, Z. \& Senturk, E. A. 2016. Sexuality and the internet: a study of the perspectives of Turkish university students. Cyberpsychology, Behavior, and Social Networking, 19(12): 740-745. 